\title{
Estimasi Simpanan Karbon Pada Ekosistem Mangrove Di Desa Pasar Banggi Dan Tireman, Kecamatan Rembang Kabupaten Rembang
}

\author{
Riani Mardliyah*, Raden Ario, Rudhi Pribadi \\ Departemen IImu Kelautan, Fakultas Perikanan dan IImu Kelautan, Universitas Diponegoro \\ Jl. Prof.H.Soedarto S.H, Tembalang,Semarang, Jawa Tengah 50275 Indonesia \\ ${ }^{*}$ Corresponding author, e-mail : rianimardliyah11@gmail.com
}

\begin{abstract}
ABSTRAK : Ekosistem mangrove memiliki fungsi ekologis sebagai penyerap dan penyimpan karbon. Mangrove menyerap $\mathrm{CO}_{2}$ pada saat proses fotosintesis, kemudian mengubahnya menjadi karbohidrat dengan menyimpannya dalam bentuk biomasa. Tujuan penelitian untuk mengestimasi simpanan karbon pada tegakan dan substrat mangrove yang berada di Desa Pasar Banggi dan Desa Tireman, Kabupaten Rembang. Pengambilan sampel dilakukan pada bulan Juni - Juli 2018. Metode yang digunakan yaitu purposive sampling method dan eksploratif, dengan dasar pertimbangan berupa jenis, kerapatan serta diameter pohon mangrove. Pengambilan sampel dilakukan di tiga stasiun dengan kondisi rapat, sedang dan jarang. Setiap stasiun penelitian dibagi menjadi tiga plot penelitian, pengukuran diameter pohon dilakukan pada transek ukuran $10 \times 10 \mathrm{~m}$, diameter yang di ukur pada setiap plot yaitu hanya kategori pohon (diameter $\geq 5 \mathrm{~cm}$ ). Berdasarkan hasil penelitian, didapat bahwa simpanan karbon pada tegakan mangrove di Desa Pasar Banggi sebesar $9.620,451$ ton/ha, dan Desa Tireman sebesar $4.633,618$ ton/ha, sedangkan estimasi simpanan karbon pada substrat mangrove di Desa Pasar Banggi sebesar 920,982 ton/ha dan Desa Tireman sebesar 471,929 ton/ha.
\end{abstract}

Kata Kunci : Mangrove; Karbon; Tegakan; Substra

\section{Estimation of Carbon Deposits in Mangrove Ecosystems in Pasar Banggi and Tireman Villages, Rembang District Rembang Regency}

\begin{abstract}
Mangrove ecosystems have ecological functions as carbon sinks and stores. Mangroves absorb $\mathrm{CO}_{2}$ during photosynthesis, then convert it to carbohydrates by storing it in the form of biomass in the body parts of mangrove plants. Research on the estimation of carbon stocks is very necessary to support the improvement of world climate. The sampling was conducted on June 2018 until July 2018. This research used purposive sampling and explorative method, with the consideration of the type, density and diameter of mangrove trees. Conducted in three stations with varying in the mangrove ecosystem conditions. Each research station was divided into three research plots, tree diameter measurements were carried out on $10 \times 10 \mathrm{~m}$ transects, the diameter measured in each plot was only trees ( $\geq 5 \mathrm{~cm}$ diameter). The result of this research, it is found that carbon storage in mangrove stands Pasar Banggi Village is 9,620,451 ton/ha, and Tireman Village is $4,633,618$ ton/ha. While estimated carbon storage the mangrove substrate in Pasar Banggi Village is 920,982 ton/ha and Tireman Village is 471,929 ton/ha. These result that estimates carbon storages in mangrove stands are greater than estimates of carbon storage on mangrove substrate. The estimation of carbon storage in the mangrove stands increases with increasing of plant biomass and mangrove density, while estimates of carbon storage on the substrate are tsuspected to be more influenced by organic matterial and the location reseach.
\end{abstract}

Keywords: Mangrove; Carbon; Stand; Substrate

\section{PENDAHULUAN}

Ekosistem mangrove, sebagaimana ekosistem hutan lainnya, memiliki kemampuan sebagai penyerap $\mathrm{CO}_{2}$, sehingga hutan mangrove memiliki peran untuk mengurangi konsentrasi 
karbondioksida di udara. Menurut Donato et al., (2011), tipe hutan mangrove memiliki kemampuan mengikat karbon jauh lebih tinggi dibandingkan dengan hutan terrestrial dan hutan hujan tropis.

Penurunan jumlah hutan mangrove akibat aktivitas manusia ataupun lainya berdampak terhadap daya serap karbon di bumi. Penurunan hutan mangrove di dunia sebesar $30-50 \%$ dalam kurun waktu setengah abad terakhir ini akibat adanya pembangunan pesisir, perluasan tambak dan penebangan pohon (Donato et al., 2011) menyadari hal itu maka diakukan upaya alternatif mengatasi permasalahan pemanasan global. Upaya tersebut antara lain dapat dilakukan melalui kegiatan rehabilitasi hutan. Menurut Cahyaningrum et al., (2014), upaya tersebut perlu didukung dengan kegiatan untuk memperoleh data dan informasi mengenai tingkat, status, dan kecenderungan perubahan emisi gas rumah kaca secara berkala dari berbagai sumber emisi dan penyerapnya, termasuk carbon stock (simpanan karbon).

Kabupaten Rembang merupakan salah satu kabupaten yang terletak di pesisir Pantai Utara Jawa Tengah yang secara geografis terletak pada $111^{\circ} 00^{\prime}-111^{\circ} 30^{\prime} \mathrm{BT}$ dan $6^{\circ} 30^{\prime}-7^{\circ} 06^{\prime}$ LS. Kabupaten ini menjadi salah satu penyebaran mangrove yang ada khususnya di Desa Pasar Banggi dan Desa Tireman, namun seiring pertambahan jumlah penduduk yang tinggal di kawasan pesisir menyebabkan tekanan terhadap ekosistem mangrove yang mengakibatkan penurunan jumlah mangrove yang ada akibat aktifitas pertambakan, penebangan mangrove dan reklamasi.

Mangrove di wilayah Rembang memiliki perbedaan diameter dan kerapatan yang disebabkan oleh perbedaan waktu penanaman, sehingga diduga akan mempengaruhi jumlah simpanan karbon yang ada. Kandungan simpanan karbon pada ekosistem mangrove di Desa Pasar Banggi dan Desa Tireman Rembang perlu diketahui sehingga hal tersebut dapat menunjang kegiatan pengelolaan kawasan secara berkelanjutan dalam kaitannya dengan pengurangan konsentrasi $\mathrm{CO}_{2}$ di atmosfer (Cahyaningrum et al., 2014).

Tujuan penelitian ini dilakukan untuk mengestimasi simpanan karbon pada tegakan dan substrat mangrove yang berada di Desa Pasar Banggi dan Desa Tireman, Kabupaten Rembang.

\section{MATERI DAN METODE}

Penelitian ini dilaksanakan di Ekosistem mangrove Desa Pasar Banggi dan Tireman Rembang. Materi pada penelitian ini adalah Ekosistem mangrove yang meliputi tegakan dan sedimen. Penentuan lokasi pengambilan sampel menggunakan metode purposive sampling dengan pemilihan sekelompok subyek didasarkan atas ciri-ciri tertentu yang dipandang mempunyai kaitan erat dengan ciri-ciri yang sudah diketahui sebelumnya (Hadi, 1979).

Pengambilan sampel dilakukan pada 6 stasiun yaitu PB 1, PB II , PB III dan TR I, TR II TR III, setiap stasiun dilakukan tiga kali pengukuran yaitu dengan total sebanyak 18 plot. Estimasi biomassa pohon dilakukan dengan metode sampling tanpa pemanenan (non-destructive), dengan mengukur semua diameter at breast height (DBH) tinggi $1.3 \mathrm{~m}$ mangrove, kemudian dilakukan perhitungan dengan model allometrik untuk menduga potensi biomassa dan simpanan karbonnya (Komiyama et al., 2005). Sedangkan untuk mengestimasi karbon sedimen dilakukan dengan pengambilan sampel sedimen pada kedalaman $30 \mathrm{~cm}$ (English et al., 1994).

Prosedur pengukuran biomasa menggunakan cara non destructive (tidak merusak individu mangrove) dengan catatan mengetahui rumus allometriknya Rumus perhitungan yang digunakan peneliti mengacu dari Komiyama et al. (2005) yaitu:

$$
\text { Wtop }=0,251 \times p \times D^{2,46}
$$

Keterangan : Wtop : Biomassa tegakan mangrove $(\mathrm{kg}) ; P$ : Kerapatan kayu $\left(\mathrm{g} / \mathrm{cm}^{3}\right)$; D : Diameter batang pohon $(\mathrm{cm})$

Nilai $p$ atau kerapatan kayu yang menjadi bahan penelitian mengenai Estimasi Simpanan Karbon pada Tegakan Ekositem Mangrove Kategori Pohon di Desa Pasar Banggi dan Tireman, Rembang ini dapat dilihat pada Tabel 1.

Untuk mengetahui densitas biomassa tegakan dalam satu petak yang berukuran $10 \times 10 \mathrm{~m}$ dalam satu plot, maka digunakan rumus sebagai berikut: 


\section{Wtop $=\frac{\sum \text { W top }}{\text { Luas Petak Ukur }}$}

Keterangan : D Wtop: Densitas biomassa seluruh tegakan $\left(\mathrm{kg} / \mathrm{m}^{2}\right) ; \sum$ Wtop : Biomassa seluruh tegakan dalam satu petak $(\mathrm{kg})$

Setelah mendapatkan nilai total biomasa dalam satuan $\mathrm{kg} / \mathrm{m}^{2}$ kemudian dikonversi kedalam satuan ton/ha. Dengan demikian, nilai estimasi simpanan karbon setiap lokasi penelitian dapat dihitung menggunakan rumus Brown (1997) sebagai berikut:

\section{T Ktop = 0,5 x T DWtop}

Keterangan : T Ktop : Total Karbon Tegakan di Lokasi Penelitian (ton/ha); T DWtop: Total biomassa tegakan di lokasi penelitian (ton/ha)

\section{Analisis Data Sedimen Mangrove}

Menurut Agus et al., (2011) nilai 1/1,724 merupakan angka konversi bahan organik dengan karbon, sehingga untuk menghitung digunakan rumus sebagai berikut:

$$
\text { Bahan Organik }=\frac{W o-W t}{W o}
$$

Keterangan : Wo: Berat Awal (g); Wt: Berat Akhir Setelah di Furnance (g)

$$
\text { Kandungan Karbon }(\mathrm{Ct})=\frac{\text { Bahan Organik }}{1,724}
$$

Untuk menghitung kandungan karbon per luasan menurut (Allen et al., 1974; Chmura et al., 2003) maka digunakan rumus sebagai berikut:

$$
\text { C tanah = Ct } \times 100
$$

Keterangan : C tanah: Kandungan Karbon Substrat per Hektar (ton/ha).

Tabel 1. Nilai Kerapatan Kayu Mangrove

\begin{tabular}{llc}
\hline No & \multicolumn{1}{c}{ Spsies Mangrove } & Nilai Kerapatan Kayu $\left(\mathrm{g} / \mathrm{cm}^{3}\right)$ \\
\hline 1 & R. stylosa & 0,9400 \\
2 & R. mucronata & 0,8483 \\
3 & R. apicullata & 0,8814 \\
4 & A. marina & 0,7316 \\
5 & S. alba & 0,6443 \\
\hline
\end{tabular}

(Sumber:www.wordagroforesty.org)

\section{HASIL DAN PEMBAHASAN}

Hasil simpanan karbon pada ekosistem mangrove yang ada di Desa Pasar Banggi memiliki nilai yang berbeda-beda. Nilai simpanan karbon tertinggi terdapat pada stasiun PB II dengan kerapatan sedang sebesar $3267 \mathrm{ind} / \mathrm{ha}$ dan memiliki nilai biomasa sebesar 549,18 ton/ha dengan jumlah total karbon sebesar 274,59 ton/ha, Sedangkan pada PB I yang memiliki kerapatan tertinggi dengan nilai 3833 ind/ha memiliki nilai biomasa sebesar 230,37 ton/ha dan total simpanan karbon sebesar 115,18 ton/ha dan Stasiun PB III yang memiliki kerapatan terendah sebesar 2133 ind/ha dengan nilai biomasa sebesar 98,97 dan total simpanan karbon 49,52 ton/ha (Tabel 2). Hasil tersebut dapat dikategorikan besar, dibandingkan dengan hasil penelitian Khairijon et al. (2013) yang telah dilakukan di hutan mangrove Marine Station Dumai yaitu diperoleh biomasa total sebesar 139,11 ton/ha atau setara dengan kandungan karbon sebesar 69,56 ton C/ha. Stasiun ini merupakan stasiun yang dekat dengan laut dan tambak, serta mempunyai dua spesies yaitu $R$. stylosa dan $R$. apiculata. 
Stasiun PB I yang memiliki nilai kerapatan tertinggi namun memiliki nilai biomasa rendah dibanding PB II yang memiliki karapatan sedang namun memiliki biomasa yang tinggi. Hal ini diduga adanya perbedaan diameter yang ada dilokasi penelitian, karena semakin besar diameter pohon semakin besar pula simpanan karbon yang ada di pohon tersebut, Pengaruh dari tingginya nilai diameter batang terhadap nilai biomassa suatu tegakan pohon sangat besar dibanding dengan kerapatan sejalan dengan pendapat Adinugroho dan Sidiyasa (2006) bahwa terdapat hubungan erat antara dimensi pohon (diameter dan tinggi) dengan biomassanya terutama dengan diameter pohon. Seiring pertumbuhan suatu tegakan pohon maka akan menghasilkan nilai biomassa dan karbon tersimpan yang besar pula karena terjadi penyerapan $\mathrm{CO}_{2}$ dari atmosfer melalui proses fotosintesis menghasilkan biomassa yang kemudian dialokasikan ke daun, ranting, batang dan akar yang mengakibatkan penambahan diameter serta tinggi pohon. Chanan (2012) menyatakan, setiap penambahan kandungan biomassa akan diikuti oleh penambahan kandungan stok karbon. Hal ini menjelaskan bahwa karbon dan biomassa memiliki hubungan yang positif sehingga apapun yang menyebabkan peningkatan ataupun penurunan biomasa maka akan menyebabkan peningkatan atau penurunan kandungan stok karbon.

Stasiun PB II yang mempunyai kerapatan sedang, memiliki biomassa dan estimasi simpanan karbon total paling tinggi dibandingkan dengan stasiun lainnya. Hal ini dipengaruhi oleh pemanfaatan biota (gastropoda, serangga, ikan, dan lain sebagainya) yang ada pada stasiun penelitian. Jika dikaitkan dengan teori menurut Steinlin (1998) bahwa adanya pengurangan biomassa yang dimanfaatkan oleh hewan herbivora, serangga, dan jasad renik.

Stasiun PB III yang memiliki kerapatan terendah sebesar 2133 ind/ha dengan nilai biomasa sebesar 98,97 dan total simpanan karbon 49,52 ton/ha. Nilai ini merupakan nilai biomasa dan cadangan karbon tegakan yang sangat jauh berbeda dengan stasiun lainya. Hal ini diduga diameter pohon yang terkecil dibandingkan dengan PB I dan PB II yang memiliki diameter pohon sekitar 5-18 cm. Hal ini sesuai (Hariah dan Rahayu , 2007) yang menjelaskan ukuran diameter batang berbanding lurus dengan nilai biomassa, semakin tinggi DBH (Diameter at Breast Hight) maka mengindikasikan semakin tua pohon tersebut dan mempunyai cadangan karbon yang lebih banyak.

Faktor yang mempengaruhi biomasa dan estimasi simpanan karbon pada tegakan mangrove adalah jenis mangrove pada suatu ekosistem. Informasi dari situs wood density (db.worldagroforestry.org), spesies Rhizophora sp. merupakan spesies yang memiliki nilai kerapatan kayu paling tinggi dibandingkan dengan spesies Avicennia sp. Kerapatan kayu Rhizophora sp. adalah 0,8-0,9 g/cm3 dan spesies Avicennia sp. memiliki 0,6-0,7 g/cm3. Perbedaan jenis mangrove inilah yang membuat pernyataan dari Hariah dan Rahayu (2007) yang menyatakan kerapatan mangrove mempengaruhi jumlah total karbon tegakan di suatu area, tidak sesuai dengan hasil dari lokasi penelitian yang ada di Desa Pasar Banggi.

Nilai simpanan Karbon yang terdapat di lokasi penelitian Desa Tireman pada stasiun TR I dengan kerapatan tinggi sebesar 2867 ind/ha memiliki nilai biomasa sebesar 375,52 ton/ha dan total simpanan karbon sebanyak 187,76 ton/ha. Untuk stasiun TR II dengan kerapatan sedang sebesar 2100 ind/ha memiliki nilai biomassa sebesar 255,28 ton/ha dan total simpanan karbon sebesar 127,64 ton/ha dan untuk kerapatan rendah TR III bernilai 1967 ind/ha memiliki nilai biomassa sebesar 213,98 ton/ha dan total simpanan karbon sebesar 106,99 ton/ha, faktor yang mempengaruhi nilai tersebut yaitu kerapatan, semakin tinggi nilai kerapatan maka semakin tinggi pula nilai simpanan karbon yang ada. Hal ini sesuai dengan pernyataan Hariah dan Rahayu (2007) menjelaskan bahwa ekosistem yang memiliki kerapatan mangrove yang tinggi akan memiliki biomassa dan simpanan karbon yang tinggi, sebaliknya ekosistem dengan kerapatan yang rendah akan memiliki biomasa dan estimasi simpanan karbon rendah. sesuai dengan pernyataan Hidaryanto et al., (2004) yang menyatakan bahwa semakin besar vegetasi mangrove yang terbentuk maka akan semakin besar simpanan karbon yang akan terdapat pada tegakan suatu vegetasi mangrove.

Perbandingan dari nilai jumlah total karbon tegakan pada Desa Pasar Banggi dan Tireman tidak begitu signifikan, hal ini ditunjukkan dari jumlah total karbon tegakan yang ada di kedua lokasi tidak berbeda jauh, hal ini disebabkan karena jenis mangrove yang tumbuh di Desa Tireman diduga pertumbuhanya lebih cepat dibandingkan dengan Desa Pasar Banggi, hal ini dapat dilihat dari nilai kerapatan kayu (wood density) dari jenis mangrove yang tumbuh di Desa Tireman, 
menurut Iswanti (2008) menyatakan perbedaan kerapatan kayu akan mempengaruhi pertumbuhan dari jenis mangrove, selain itu luasan dari kedua lokasi yang berbeda al ini juga dapat mempengaruhi total karbon yang ada dalam suatu area.

Selain perbedaan ukuran diameter, jumlah individu, kerapatan dan jenis mangrove, faktor yang diduga mempengaruhi potensi simpanan karbon di ekosistem mangrove Rembang adalah adanya alih fungsi lahan. Desa Pasar Banggi merupakan lokasi yang dimanfaatkan sebagai ekowisata, sehingga kondisi mangrove di lokasi tersebut masih terjaga. Sementara itu lokasi penelitian Desa Tireman berada di area pertambakan. Hal ini diduga bahwa luasan mangrove di Desa Tireman telah dialihfungsikan sebagai tambak oleh masyarakat sekitar, sehingga jumlah mangrove yang terdapat di lokasi ini lebih sedikit dibandingkan dengan Desa Pasar Banggi.

Berdasarkan hasil yang didapat pada penelitian maka didapatkan nilai simpanan karbon pada substrat, untuk Desa Pasar Banggi simpanan karbon tertinggi berada pada stasiun PB II dengan nilai 23,299 dan nilai bahan organik sebesar 40,167, untuk stasiun PB I memiliki nilai simpanan karbon sebesar 12,471 dan kandungan bahan organik sebesar 21,500 sedangkan untuk PB III memiliki kandungan karbon 6,284 dan bahan organik sebesar 10,833 (Tabel 3). Untuk Desa Tireman memliki nilai simpanan karbon tertinggi terdapat pada stasiun TR I dengan nilai 21,228 dan kandungan bahan organik sebesar 37,167, diikuti dengan TR II yang memiliki nilai simpanan karbon sebesar 14,018 dan kandungan bahan organik sebesar 24,167 selanjutnya untuk simpanan karbon yang terendah terdapat pada stasiun TR III senilai 7,44 dan kandungan bahan organik senilai 12,833. Hasil kandungan karbon pada substrat mangrove dipengaruhi oleh banyaknya bahan organik yang ditemukan. Nilai simpanan karbon didapat dari konversi 1/1,724 untuk semua stasiun. Sehingga semakin besar nilai bahan organik maka semakin tinggi pula simpanan karbon di setiap stasiun. Hal ini sesuai (Agus et al., 2011), massa karbon untuk setiap satuan berat tanah adalah kandungan bahan organik Bahan organik memiliki definisi yaitu tumbuhan dan hewan yang tersisa dan sudah maupun sedang mengalami pelapukan yang berada di dalam tanah (Winarso, 2005). Sabarnuddin (2002) menjelaskan sumber bahan organik yang utama yaitu jaringan tumbuhan yang berasal dari daun, akar, kayu, rumput, dan semak. Jadi, dapat disimpulkan bahwa bahan organik pada sedimen mangrove dipengaruhi oleh serasah pohon mangrove yang sudah ke sedimen dan mengalami dekomposisi sehingga membuat nilai bahan organik berbeda-beda.

Nilai total estimasi simpanan karbon pada substrat di Desa Pasar Banggi dengan luas 21,90 adalah 920,982 ton/ha. Hasil penelitian ini juga lebih tinggi jika dibandingakan dengan hasil penelitian Sofyan et al., (2016) di Kawasan Pesisir Rupat Utara yang memiliki rata-rata karbon organik sebesar 904,75 ton/ha. Hasil karbon organik ini lebih tinggi jika dibandingkan dengan penelitian yang dilakukan oleh Handoko et al., (2016) di Kawasan Selatan Pulau Rupat yang hanya memiliki karbon organik sebesar 920,12 ton/ha. Tetapi hasil penelitian ini lebih kecil jika dibandingkan dengan penelitian Massugito (2015) di Kawasan Pesisir Kuala Indragiri yang memiliki rata-rata karbon organik yang lebih tinggi, yaitu sebesar 1.476,40 ton/ha. Dari hasil tersebut dapat disimpulkan bahwa potensi simpanan karbon di Pasar Banggi tidak hanya karbon mangrovenya saja yang besar, tetapi karbon organiknya juga besar.

Tabel 2. Jumlah Total Estimasi Simpanan Karbon Pada Tegakan di Lokasi Penelitian di Rembang

\begin{tabular}{ccccc}
\hline Lokasi & $\begin{array}{c}\text { Stasiun 1 } \\
\text { (ton/ha) }\end{array}$ & $\begin{array}{c}\text { Stasiun 2 } \\
\text { (ton/ha) }\end{array}$ & $\begin{array}{c}\text { Stasiun 3 } \\
\text { (ton/ha) }\end{array}$ & $\begin{array}{c}\text { Total Karbon } \\
\text { Tegakan(ton/ha) }\end{array}$ \\
\hline Pasar Banggi & 115,18 & 274,59 & 49,52 & 439,29 \\
Tireman & 187,76 & 127,64 & 106,99 & 422,39 \\
\hline
\end{tabular}

Tabel 3. Jumlah Total Estimasi Simpanan Karbon Pada Berbagai Stasiun Lokasi Penelitian di Rembang

\begin{tabular}{ccccc}
\hline Lokasi & $\begin{array}{c}\text { Stasiun 1 } \\
\text { (ton/ha) }\end{array}$ & $\begin{array}{c}\text { Stasiun 2 } \\
\text { (ton/ha) }\end{array}$ & $\begin{array}{c}\text { Stasiun 3 } \\
\text { (ton/ha) }\end{array}$ & $\begin{array}{c}\text { Total Karbon } \\
\text { sedimen (ton/ha) }\end{array}$ \\
\hline Pasar Banggi & 12,471 & 23,299 & 6,284 & 42,054 \\
Tireman & 21,558 & 14,018 & 7,444 & 43,02 \\
\hline
\end{tabular}


Total simpanan karbon akan diestimasi dengan jumlah luasan pada lokasi penelitian. Total simpanan karbon pada tegakan di Desa Pasar Banggi adalah 9.620,451 ton /ha dengan luas area sebesar 21,90 ha, sedangkan total simpanan karbon di Desa Tireman adalah 4.633,618 ton/ha dengan luas area sebesar 10,97 ha. Total simpanan karbon pada substrat di Desa Pasar Banggi adalah 920,982 ton /ha dengan luas area sebesar 21,90 ha, sedangkan total simpanan karbon di Desa Tireman adalah 471,929 ton/ha dengan luas area sebesar 10,97 ha.

\section{KESIMPULAN}

Hasil estimasi simpanan karbon pada tegakan di ekosistem mangrove Desa Pasar Banggi sebesar 9.620,451 ton/ha dan Desa Tireman sebesar 4.633,618 ton/ha. Hasil estimasi simpanan karbon pada substrat di ekosistem mangrove. Desa Pasar Banggi sebesar 920,982 ton/ha dan Desa Tireman sebesar 471,929 ton/ha. Semakin besar diameter pohon semakin tinggi simpanan karbon, sebaliknya semakin kecil diameter pohon semakin sedikit simpanan karbon. Selain itu semakin tinggi nilai kerapatan pohon maka semakin tinggi simpanan karbon, sebaliknya semakin kecil nilai kerapatan pohon maka semakin kecil juga simpanan karbon yang ada.

\section{DAFTAR PUSTAKA}

Adinugroho, W.C. \& Sidiyasa, K. 2006. Model Pendugaan Biomassa Pohon Mahoni (Swietenia macrophylla King) di atas Permukaan Tanah. Jurnal Penelitian Hutan dan Konservasi Alam, 3(1):103-117

Agus, F., Hariah, K. \& Mulyani, A. 2011. Measuring Carbon Stock in Peat Soil: Practical Guidelines. World Agroforesty Centre (ICRAF) and Indonesian Soil Research Institue. Bogor, $154 \mathrm{hlm}$.

Allen, S.E., Grimshaw, H.M., Parkinson, J.A. \& Quarmby, C. 1974. Chemical Analysis of Ecological Materials. New York, $565 \mathrm{hlm}$.

Brown, S. 1997. Estimating Biomass and Biomass Change of Tropica Forest. A Forest Resource Assesment Publik. $134 \mathrm{hlm}$.

Cahyaningrum, S.T., Hartoko, A. \& Suryanti. 2014. Biomassa karbon mangrove pada kawasan mangrove Pulau Kemujan Taman Nasional Karimun Jawa. Journal of Maquares. 3(2):34-42

Chanan, A. 2012. Pendugaan Biomasa Karbon Tersimpan pada Ekosistem Mangrove Kelurahan Meras. Fakultas Pertanian Universitas Samratulangi.Manado

Chmura, G.L., Anisfield, S.C., Cahoon, D.R. \& Lynch, J.C.. 2003. Global Carbon Sequestration in Tidal, Saline Wetland Soils. Global Biogeochemical Cycles, 17(4):1-12

Donato, C.D., Kauffman, J., Murdiyarso, B., Kurnianto, S., Stidham, M \& Kanninen, M. 2011. Mangroves among the most carbon-rich forests in the tropics. Nature Geoscience. 4:293297.

English, S., Wilkinson, C. \& Baker, V. 1994. Survey Manual for Tropical Marine Resources. Australian Institute of Marine Science, $390 \mathrm{hlm}$.

Hadi, S. 1979. Metodology Research II. Yayasan Penerbit Fakultas Psikologi. UGM. Yogyakarta

Handoko, E., Bintal, A. \& Siregar, S. H. 2016. Analisis Biomassa dan Cadangan Karbon Pada Ekosistem Mangrove di Kawasan Selatan Pulau Rupat. Universitas Riau. Pekanbaru

Hariah, K., \& Rahayu, S. 2007. Pengukuran Karbon Tersimpan di Berbagai Macam Penggunaan Lahan. World Agroforestry Centre ICRAF. Bogor, $21 \mathrm{hlm}$.

Hidaryanto, W., Heru, A. \& Yosita. 2004. Analisa Tanah Tambak sebagai Indikator Tingkat Kesuburan Tambak. Jurnal Pengkajian dan Pengembangan Teknologi Pertanian. Jurnal Pengkajian, 7(2):180-186.

Iswanti, 2008. Ekologi Hutan. Jakarta: Penerbit PT Bumi Aksara.

Khairijon, K., Fatonah, S. \& Rianti, A.P., 2013. Profil Biomassa dan Kerapatan Vegetasi Tegakan Hutan Mangrove di Marine Station Kecamatan Dumai Barat, Riau. Prosiding Semirata 2013, $1(1)$.

Komiyama, A., Poungpam, S. \& Karto, S. 2005. Common Allometric Equations for Estimating The Tree Weight of Mangroves. Journal of Tropical Ecology, 21(4):471-477 
Massugito, M., Nedi, S. \& Amin, B., Analysis of Carbon Reserves in the Mangrove Forest Ecosystem of Kuala Indragiri Riau Province. Jurnal Online Mahasiswa Fakultas Perikanan dan Ilmu Kelautan Universitas Riau, 2(2):1-9.

Sabarnuddin, M. S. 2002. Bahan Kuliah Agroforestry Bagian 4: Produktivitad dan Perlindungan Hutan. Fakultas Kehutanan Universitas Gadjah Mada. Yogyakarta Saenger, P., E. Hegerl, and J Devie (eds). 1983. Global Status of Mangrove Ecosystems. Commission on Ecology Papers, No. 3. International Union for the Conservation of Nature and Natural Resources, Gland, Switzerland

Sofyan, M., \& Aras, M.E. 2016. Analysis of Biomass and Carbon Stock on Mangrove Forest Ecosystem in North Coastal Area of Rupat Island Riau Province. Universitas Riau. Riau.

Steinlin, H. 1998. Menuju Kelestarian Hutan. Yayasan Obor Indonesia, Jakarta.

Winarso. 2005. Kesuburan Tanah. Gava Media. Yogyakarta. 